\title{
Institutions and State Authorities of the Republic of Poland Involved in Cross-Border Security
}

\author{
Instytucje i organy państwowe na rzecz bezpieczeństwa transgranicznego \\ Rzeczypospolitej Polskiej
}

\section{- Abstrakt •}

Bezpieczeństwo transgraniczne jest częścią bezpieczeństwa zewnętrznego i bezpieczeństwa wewnętrznego państwa - odpowiedzialność za nie jest zazwyczaj podzielona. Polska administracja graniczna zarówno w sensie podmiotowym, jak i przedmiotowym jest niejednolita. Konstytucja Rzeczypospolitej Polskiej w art. 146 wskazuje, że Rada Ministrów, a w szczególności Minister Obrony Narodowej, minister właściwy do spraw wewnętrznych i minister właściwy do spraw finansów publicznych zapewniają bezpieczeństwo zewnętrzne i bezpieczeństwo wewnętrzne oraz porządek publiczny w państwie. W mniejszym stopniu odpowiedzialność za bezpieczeństwo granicy ponoszą też inni ministrowie nadzorujący centralne organy administracji rządowej mające w swoim zakresie działania zadania ochronne granicy państwowej. Bardzo ważne funkcje bezpośrednio lub pośrednio związane z bezpieczeństwem granicy wykonują wojewodowie.

Autor charakteryzuje poszczególne instytucje i organy państwowe, wykazując ich wpływ na poziom bezpieczeństwa transgranicznego Rzeczypospolitej Polskiej.

\section{- Abstract •}

Cross-border security is part of both external and internal security of a state; hence the responsibility for it is usually divided. Similarly, the responsibility for Polish border administration is split in both subjective and objective sense. The Constitution of the Republic of Poland in art. 146 indicates that the Council of Ministers, and in particular the Minister of National Defence, the Minister competent for Internal Affairs and the Minister competent for Public Finance shall ensure external and internal security as well as public order in the state. To a lesser extent, the responsibility for state security is also shared by other ministers supervising central administration bodies that have state border protection within their scope.

In addition, very important functions directly or indirectly related to border security are carried out also by voivodes.

In the current paper, the author presents individual institutions and state bodies involved in cross-border security of the Republic of Poland, demonstrating their impact on the overall level of this security. 
Słowa kluczowe: granica państwowa; bezpieczeństwo transgraniczne; kontrola graniczna; służby graniczne; celne; weterynaryjne; sanitarne; współpraca transgraniczna
Keywords: sstate border; cross-border security; border control; border services; border guards; customs; veterinary; sanitary; cross-border cooperation

\section{Introduction}

As cross-border security is part of both external and internal security of a state, the responsibility for it is usually split - this is also the case in Poland. Responsibility for the Polish border administration is divided in both the subjective and objective sense. The Constitution of the Republic of Poland in art. 146 indicates that the Council of Ministers, and in particular the Minister of National Defence, the minister competent for internal affairs and the minister competent for public finance shall ensure external and internal security, as well as public order in the state. To a lesser extent, the responsibility for border security is also shared by other ministers supervising central administration bodies that have state border protection within their scope of tasks. Very important functions directly or indirectly related to border security are carried out also by voivodes.

In turn, according to art. 7 of the Act on State Border Protection, the minister competent for internal affairs is responsible for protection of state borders on land and sea, as well as for border traffic control, to the extent specified in separate regulations. These tasks are implemented by the Chief Commander of the Border Guard. The Minister of National Defence is responsible for protection of state borders as concerns airspace of the Republic of Poland, and the resulting tasks related to airspace protection are performed by the Armed Forces General Command supported by the air defence command.

\section{Border Guard}

The Border Guard is the main service force ensuring Poland's cross-border security. It is a police-type formation - unified, uniformed and armed - established to protect the state borders, control border traffic, and prevent and counteract illegal migration. In its character and structures as well as in methods of carrying out its tasks it complies with legal provisions in force across the European Union countries and cooperates with border services of these countries. Due to diversity of cross-border threats and conditions of their occurrence, the legislator has defined 
a wide range of the border guard's tasks. The Border Guard Act ${ }^{1}$ lists the following tasks:

1) protection of the state border on land and sea;

2) organizing and conducting border traffic controls;

3) preventing and counteracting illegal migration;

4) issuing permits to cross the state border, including visas;

5) recognizing, preventing, detecting and prosecuting perpetrators of crimes and offenses falling within scope of Border Guard responsibilities as prescribed by law;

6) ensuring security in international transport and public order within boundaries of the border crossings, as well as in near-border areas in matters falling within scope of Border Guard responsibilities as prescribed by law;

7) conducting security checks: in means of transport in international transit; within the territorial range of road, rail, sea and river border crossings; at airports under the rules set out in provisions on civil aviation security;

8) ensuring safety onboard aircraft used for air transport of passengers;

9) cooperation with other authorities and service forces in identifying and preventing terrorism threats;

10) setting up and maintenance of border signage on land and preparation, updating and storage of border geodetic and cartographic documentation;

11) protection of inviolability of signage and items and devices used to secure the state border;

12) collecting and processing information on protection of the state borders, border traffic control, prevention and counteracting of illegal migration, and making them available to competent state authorities;

13) supervision of operations in Polish marine areas and ensuring compliance of vessels with the regulations in force in these areas;

14) protection of the state border in the airspace of the Republic of Poland through observation of aircraft and flying objects passing through the state border at low altitudes, and passing of information on these movements to the competent units of the Polish Air Force;

15) preventing cross-border transportation of waste, harmful chemical substances and nuclear and radioactive materials without a permit required under separate regulations and preventing pollution of border waters;

16) counteracting cross-border transports of narcotic drugs and psychotropic substances as well as weapons, ammunition, explosives and precursors of 
explosive materials subject to restrictions without authorization required under separate regulations,

17) performing tasks specified in other acts.

The Commander-in-Chief of the Border Guard is the central administration body competent in the matters of state border protection and border traffic control, subordinate to the Minister competent for Internal Affairs. They perform the tasks assigned with the support of the specially appointed organizational unit, i.e. Border Guard Headquarters situated in Warsaw, and headed by the Commandant and their deputies. In turn, in various regions the BG is represented by commanders of regional Units and commanders of border posts. Offices of Unit commanders serve as Headquarters of regional units, while commanders of border posts and divisions are executing their tasks with support of staff of local border posts and border divisions.

In the organizational structure of the Border Guard there are 9 Border Guard Regional units ${ }^{2}$, including: six BG regional units the main task of which is to protect sections of the EU/Schengen external borders, conduct border checks at border crossings and carry out immigration service tasks on the state territory. The structures of Border Guard units include border guard posts and border guard divisions. In addition, the BG organizational structure includes also three training centres and a BG archive.

The Border Guard officers have been given numerous rights enabling them to perform the tasks they are assigned. These include the right of:

1) carrying out border controls;

2) carrying out personal checks;

3) performing security checks at border crossing points, at airports and in means of air, road, rail and water transport;

4) performing guard duties on aircraft;

5) issuing visas and other permits to cross the state borders;

6) demanding presentation of identity documentation or using other means to identify a person;

7) stopping, convoying and escorting people;

8) carrying out searches on people, items, on premises and in means of transport as part of the procedures and in cases specified in the Code of Criminal Procedure and other legal acts;

2 The Border Guard Regional Unit is a basic and independent organizational unit of the Border Guard, designed to protect the state border on the territory of one or two provinces, most often where a national border is delimited, with diversified full-time staff, the size of which is adjusted depending on needs. 
9) imposing fines for offenses;

10) observing and recording events on roads and in other public places, using technical means allowing for recording of both image and sound;

11) stopping vehicles and performing other activities as part of road traffic control;

12) stopping harmful nuclear and radioactive materials, chemical and biological agents as well as waste at the state border and returning them to the sender;

13) right to demand necessary assistance from state institutions, state and local administration bodies as well as public services units and companies;

14) demanding necessary help from other commercial entities and social organizations, as well as - in emergencies - applying for immediate help to any individual, all within the framework of applicable laws.

The Border Guard has been granted specific powers also based on the provisions of migration law, including as concerns legality control of stays of foreigners on the territory of the Republic of Poland ${ }^{3}$.

\section{Voivodes}

An important role is played by voivodes, key administration bodies of local governments. The Act on State Border Protection stipulates that a voivode is obliged to permanently maintain road, rail, sea and river border crossings, border crossings intended only for local border traffic, tourist crossings, border crossings on tourist routes crossing the state border, border crossing points on tourist routes as well as night stopovers on border rivers within the territory of their voivodship in a condition enabling efficient and effective control of security, border checks, customs checks, and sanitary, veterinary, phytosanitary, chemical and radiometric checks and verification of commercial quality of agro-food products. The voivode is also required to permanently maintain air border crossing points in a condition that allows for efficient and effective pyrotechnical controls, with the exception of security checks performed by airport managing entity or other authorized party as per the rules set out in provisions on civil aviation security.

The voivode is similarly obliged to provide border service forces with appropriate premises to serve as their base as well as equipment and technical means neces-

\footnotetext{
3 See: Act on Foreigners of 12 December 2013; OJ of 2016, item 1990.
} 
sary to carry out efficient and effective controls. Costs related to the financing and maintenance of border crossings are covered from the voivodship funds ${ }^{4}$.

\section{National Revenue Administration - Customs and Tax Services}

Another important institution in the state's cross-border security system is the National Revenue Administration, supervising international trade in goods. The legal basis for the functioning of this institution is the Act of 16 November 2016 on National Revenue Administration ${ }^{5}$, together with implementing acts ${ }^{6}$. The National Revenue Administration is a specialized central administration body performing tasks related to implementation of revenue from taxes, customs duties, fees and non-tax budgetary claims, protection of interests of the National Treasury and protection of the European Union customs area. It is also tasked with providing services and support to taxpayers and payers in proper performance of their tax obligations, and to entrepreneurs in correct performance of their customs duties.

The Customs and Tax Service - a unified and uniformed formation - forms part of the National Revenue Administration. The basic tasks of the Customs and Tax Service include?:

1) control of compliance with customs legislation and other regulations in all exports and imports of goods;

2) performing activities related to assigning goods to a customs-approved destination;

3) calculation and collection of customs duties and other charges related to imports and exports of goods;

4) calculation and collection of value added tax (VAT) on imports of goods;

5) control, special tax supervision, calculation and collection of excise duty;

6) collection of fuel surcharge;

7) control of gambling, gaming and betting;

${ }^{4}$ See: Regulation of the Council of Ministers regarding the responsibilities of the voivode in the area of financing and maintenance of border crossings, tourist crossings, border crossing places on tourist routes and night stops at border rivers, their equipment, as well as authorities competent for embedding and maintaining border signs in sea waters of 13 December 2005; OJ No 256, item 2145.

5 OJ of 2016, item 1947.

${ }^{6}$ OJ of 2016, item 1948.

7 OJ of 2016, item 1947. 
8) performing tasks resulting from the Act of 19 November 2009 on games of chance, related in particular to the granting of licenses, concessions and permits, approval of internal regulations of gaming operators and registration of equipment;

9) cooperation in implementation of the Common Agricultural Policy;

10) performance of tasks resulting from the EU provisions regulating statistics on trade in goods between Member States of the European Union;

11) recognition, prevention and detection of fiscal offenses and fiscal violations, offenses related to imports and exports of goods and prosecution of perpetrators, to the extent specified by other laws;

12) identifying, preventing and detecting offenses and violations of regulations on protection of cultural property and intellectual property, as well as offenses related to introduction into Polish customs territory and removal from the Polish customs territory of goods subject to restrictions or prohibitions, in particular: harmful waste, chemical substances, nuclear and radioactive materials, narcotic drugs and psychotropic substances as well as weapons, ammunition, explosives and technologies controlled internationally;

13) traffic control;

14) control of road transport;

15) cooperation with customs authorities of other countries and international organizations;

16) cooperation with the Head of the National Criminal Information Centre to the extent necessary to carry out its statutory tasks.

To be able to carry out these tasks, officers of the Customs and Tax Service have been granted the right to:

1) stop and search people, confiscate items and search residences and other premises and locations, including performing searches of luggage, cargo and means of transport as part of procedures and in cases specified in the provisions of the Code of Criminal Procedure;

2) confiscate and search devices or media containing data, as concerns full scope of data stored on these devices and in their systems, including correspondence sent via email as part of procedures and in cases specified in the provisions of the Code of Criminal Procedure;

3) detain persons as a result of a chase in order to immediately hand them over to customs officers of a competent EU Member State;

4) detain persons and objects whose data has been entered into the Schengen Information System and the Visa Information System in order to take up 
the action specified in the relevant entry, or to transfer the person or object to the relevant authorized entity without delay;

5) convoying and escorting persons according to the rules specified in relevant regulations;

6) impose fines for fiscal offenses and petty offenses in circumstances and conditions set out in applicable regulations;

7) demand necessary help form other organizational units, companies and social organizations, as well as - in emergencies - applying for immediate help to any individual, within the framework of applicable laws.

\section{Veterinary, Sanitary, Phytosanitary Control and Quality Control at State Borders}

The Veterinary Inspection is another important entity involved in ensuring security of the state borders, especially border traffic. Its functioning is regulated by the Act of 29 January 2004 on the Veterinary Inspection ${ }^{8}$. The main tasks of the Inspection are focused on protection of animal health and safety of products of animal origin. One of the many tasks of the Inspection is to carry out veterinary border controls. According to the Act of 27 August 2003 on veterinary border controls ${ }^{9}$, such a check may consist in:

1) document control - checking of veterinary certificates or other documents accompanying the transport;

2) identity check - visual inspection and confirmation of compliance of veterinary certificates or documents accompanying the consignment with its physical characteristics or checking and confirming the placement of markings on animals or products is in compliance with the content of veterinary certificates or documents accompanying the consignment;

3) physical control of animals - checks including taking samples from animals and laboratory testing of these samples, and if required also additional checks during quarantine;

4) product controls including, in particular, checks of packaging and temperature controls, as well as sampling and laboratory testing;

5) additional checks carried out in case of suspected violations of national or EU regulations, or in case of doubts as to the identity of the animal.

8 OJ of 2015, items 1482, 1918; OJ of 2016, item 50.

9 OJ of 2014, items 424, 1662; OJ of 2016, item 1228. 
Each consignment of animals or products introduced from third countries is subjected to veterinary border control, while consignments from the territory of the European Union are exempt from export controls. In order to carry out these controls effectively, the Veterinary Inspection authorities use the EU-wide IT systems ${ }^{10}$.

The next body contributing to safety of the state borders as concerns sanitary matters is the State Sanitary Inspection, operating on the basis of the Act of 14 March 1985 on the State Sanitary Inspection ${ }^{11}$. It was appointed to perform tasks in the field of public health, in particular by exercising supervision over:

1) environmental hygiene;

2) occupational hygiene in workplaces;

3) radiation hygiene;

4) hygiene in education processes of all levels;

5) hygiene of rest and recreation activities;

6) quality and safety of foodstuffs and in gastronomy outlets;

7) hygienic and sanitary conditions which should be met by medical personnel, equipment and premises where medical services are provided in order to protect human health from harm and environmental nuisances, and prevent diseases, including infectious and occupational diseases.

Inspection of border crossing points, airports and seaports as well as vessels operating in the Polish territorial waters is performed by state border sanitary inspectors who manage border sanitary and epidemiological stations ${ }^{12}$. Border sanitary controls are aimed at maintaining security of the state and ensuring effectiveness of its sanitary and epidemiological protections - specifically, preventing introduction of foodstuffs, materials and products intended for contact with food items on the territory of Poland and the European Union, the quality of which does not comply with the applicable health and sanitary regulations and thus may pose a threat to human health and life. As part of implementation of their statutory tasks, state border sanitary inspectorates monitor threats and assess the epidemiological situation along the state borders, stopping the entry of particularly dangerous, highly contagious diseases onto the Polish territory and protecting the state from bioterrorist attacks. These tasks are performed by 10 border sanitary and epidemiological stations ${ }^{13}$.

${ }^{10}$ See: Główny Inspektorat Weterynarii. Retrieved from: www.wetgiw.gov.pl.

${ }^{11}$ Annex to the announcement of the Speaker of the Lower House of the Polish Parliament of 8 June 2017, item 1261.

12 See: Główny Inspektorat Sanitarny. Retrieved from: www.gis.gov.pl.

13 Regulation of the Minister of Health of 19 July 2002 on the list of border sanitary and epidemiological stations. 
The State Plant Health and Seed Inspection Service is of equal importance in ensuring the safety of Polish borders, especially border traffic. The scope of the Inspection's responsibilities is regulated by the Act of 18 December 2003 on plant protection ${ }^{14}$. The tasks of the Inspectorate are carried out under supervision of the Chief Inspector and the voivode, with support of the voivodship regional inspectors as heads of plant health and seed inspection services at the level of provincial administration. The inspection observes and inspects plants, plant products or objects in order to determine the presence of harmful organisms posing a particular threat, and hitherto not occurring in Poland or the occurrence of which is not widespread and stop them from crossing the border. If such are revealed or suspected to be present, the Voivodship Inspector for Plant Health and Seed Inspection identifies the harmful organism and its origin, assesses the possibilities of further spread of this organism and options for its eradication. Whenever plants, plant products and objects are imported to Poland directly from countries outside the European Union, they are subjected to phytosanitary border inspection. All the above activities are performed by inspectors of Border Units of the State Plant Health and Seed Inspection Service in various points of entry.

The Agricultural and Food Quality Inspection, whose operation is regulated by the Act of 21 December 2000 on commercial quality of agri-food products ${ }^{15}$ also belongs to the group of agencies responsible for border security. The tasks of the Inspection are carried out by the Chief Inspector for Agricultural and Food Quality jointly with the voivode, supported in turn by the voivodship inspector for commercial quality of agri-food products, heading the provincial office of the Inspection.

For the purposes of the conducted analysis, the most important aspect of tasks of this particular Inspection is control of commercial quality of agri-food and food products traded with foreign countries; such products imported from abroad are controlled at border crossings. The checks extend to the following goods:

- agricultural and food products imported from abroad and imported fresh fruit and vegetables,

- fresh fruit and vegetables intended for exports outside Poland.

${ }_{14}$ The announcement of the Speaker of the Lower House of the Polish Parliament of 30 October 2017 regarding publication of the uniform text of the Act on Plant Protection, Warsaw, 21 November 2017; OJ item. 2138.

15 OJ of 2017, item 2212. 


\section{Police}

An important role in ensuring security of the state borders is played by the Police. Although this formation does not take any action directly related to physical protection of the state borders or border control, its activities also encompass combating cross-border crime and terrorist threats, as well as cooperation with the Border Guard, the Customs and Tax Services and with foreign partners in accordance with internal regulations and relevant international agreements. The police are a uniformed and armed formation serving the public and established to protect people's safety and to maintain public safety and order. It operates on the basis of the Act of 6 April 1990 on the Police ${ }^{16}$. The Police also perform tasks regulated in European Union law and international agreements according to the terms and within the scope specified therein, as well as tasks assigned on the basis of the Act of 9 March 2017 on the system of monitoring the carriage of goods by road ${ }^{17}$.

In the airport safety and security system, the Police implements the provisions resulting from the Act on the Police as well as Aviation Law. Tasks within the scope of Police responsibilities are carried out on a permanent or ad hoc basis by officers from Police airport units. In addition, airports have separate police stations. An Airport Police Station is a specialized police station entrusted with a number of important tasks, including: ensuring the safety of persons staying at the airport, preventing acts of terror, sabotage and subversion in air transport, combating common crime and protecting property in the subordinate area, observing passengers departing and arriving, etc. Similar specialized police stations carry out analogous tasks to ensure safety of sea borders in the territorial sea and internal sea waters. The district commander of the Police and the commandant of the specialist police station are jointly responsible for proper organization of operations on water. The most important tasks of the Water Police include: prevention of crime, misdemeanours and other events disturbing safety and order on water, detection of crimes and offenses, prosecution of perpetrators, cooperation in the field of rescue, protection of safety and order on water and ecology ${ }^{18}$. Furthermore, poviat headquarters of the Police in poviats directly neighbouring the state border contribute to maintaining safety of these borders, as regulated in the Police Act and related executive acts.

16 OJ of 1990 no 30 item 179 .

17 OJ item 708.

18 See: Regulation No. 841 of the Police Commander-in-Chief of 26 July 2004 on the methods and forms of performing tasks by police officers serving on water and land. 


\section{Armed Forces}

Security of the state air border is entrusted to the Air Force of the Republic of Poland. It is implemented as part of the Polish Air Defence system in cooperation with the NATO Integrated Air Defence System. Responsibility for protecting the state border in the airspace belongs to the Minister of National Defence; execution of tasks in this area is delegated to the General Command of Armed Forces that also acts as the chief organising body of the Polish Air Defence system during peacetime.

The Air Defence System of the Republic of Poland is made up of forces and resources organized into a specific structure and allocated to ensure safety of the air space, in particular protection of important political and administrative objects, military, defence-related and other critical infrastructure, troops and populations on the territory of Poland against attacks from air. The Polish Air Defence System is a component of the state's defence system ${ }^{19}$. According to point 6 of the decision of the Minister of National Defence, the General Command of Armed Forces is responsible for ensuring the proper functioning of the Polish Air Defence System. In the case of a threat of air attacks, in the space, the General Command directs cooperation with other state and allied operations centres and coordinates these institutions; the Command also cooperates with services of neighbouring states that are not members of NATO, sends alert signals to the forces on duty, determines the degree of threat, selects and activates emergency airports on which civil and military aircraft are forced to land by intercepting aircraft. The state border protection in the airspace is complemented by continuous radiolocation analysis system, sending alerts and notifications about airborne threats, providing assistance to aircraft crews and conducting search and rescue operations.

\section{Other Services}

Although the Airport Security Service is not a state service, it has been included in this analysis due to its competences to provide security at air border crossing points. The Airport Security Service is an internal security service or specialist armed protective formation operating on the basis of the Act of 22 August 1997

19 Decision No. 416/MON of the Minister of National Defence of 23 December 2013 on the functioning of the air defence system of the Republic of Poland in time of peace and division of competences between the Chief of General Staff of the Polish Army, Operational Commander of the Armed Forces and the General Commander of the Armed Forces in this regard. item 372. 
on the protection of persons and property ${ }^{20}$. Such forces are formed at airports and are subordinate to the airport managing authority. The Service ensures the safety of passengers, aircraft and employees throughout the entire airport. The most important tasks of the Airport Security Service include, among others: conducting security checks of persons, baggage, cargo, mail, on-board supplies and airport-side supplies, access control to security restricted areas, control of passes issued by the airport manager, guarding of security restricted areas and other zones. When performing the above tasks, the Airport Security Service cooperates with other relevant departments or authorities operating at the airport. If it is necessary to carry out tasks exceeding the competences of the Airport Security Service, the airport managing authority notifies the Border Guard or the Police.

\section{Summary}

The presented institutions and state entities play an important and highly responsible role in protecting cross-border security of Poland and the European Union. Their activities focus on ensuring the security of the Polish state borders - these same borders being also either internal or external borders of the European Union. The contemporary security environment, its dynamism and unpredictability require close cooperation, joint activities and complementarity between actions performed at various levels. The current set up of these processes forms a flexible and efficiently functioning system.

\section{References:}

Act on Foreigners of 12 December 2013. (2013). OJ of 2016, item 1990.

Decision No. 416/MON of the Minister of National Defence of December 23, 2013 on the functioning of the air defence system of the Republic of Poland in time of peace and division of competences between the Chief of General Staff of the Polish Army, Operational Commander of the Armed Forces and the General Commander of the Armed Forces in this regard. (2013). Item 372.

OJ of 2014. (2014). Items 24, 628, 424, 1165, 1199, 1662.

OJ of 2015. (2015). Item 497, 1482, 1607, 1918.

OJ of 2016. (2016). Item 50, 904, 1001, 1228, 1432, 1579, 2255.

OJ of 2017. (2017). Items 60, 2365, 2405.

OJ of 2018. (2018). Items 106, 138, 650, 730, 894, 1203, 1544.

${ }^{20}$ OJ of 2016 items 1432 and 2255 and OJ of 2017, item 60. 
Regulation No. 841 of the Police Commander-in-Chief of 26 July 2004 on the methods and forms of performing tasks by police officers serving on water and land. (2004).

Regulation of the Council of Ministers regarding the responsibilities of the voivode in the area of financing and maintenance of border crossings, tourist crossings, border crossing places on tourist routes and night stops at border rivers, their equipment, as well as authorities competent for embedding and maintaining border signs in sea waters of 13 December 2005. (2005). OJ No 256, item 2145.

The announcement of the Speaker of the Lower House of the Polish Parliament of 10 March 2017 regarding publication of the uniform text of the Act on State Border Protection. (2017). Warsaw; OJ of 28 March 2017, item 660.

The announcement of the Speaker of the Lower House of the Polish Parliament of 30 October 2017 regarding publication of the uniform text of the Act on Plant Protection. (2017). Warsaw; OJ of 21 November 2017, item 2138. 